\title{
N a turalista e homem público: a trajetória do ilustrado José Bonifácio de Andrada e Silva em sua fase portuguesa (1780-1819)
}

\author{
Alex Gonçalves Varela \\ Programa de Pós-Graduação em Educação \\ Aplicada às Geociências - IGE/Unicamp \\ Maria Margaret Lopes \\ Educação Aplicada às \\ Geociências - IGE/Unicamp \\ Maria Rachel Fróes da Fonseca \\ Departamento de Pesquisa da Casa \\ de Oswaldo Cruz/Fiocruz
}

RESUM 0 : José Bonifácio de Andrada e Silva tem sua presença marcada na historiografia de forma quase que consensual em torno de sua identifica ção como o Patria rca da Independência, o que corresponde ao seu perfil de estadista e parlamentar. Contudo, ele notabilizou-se não apenas como homem público, mas ta mbém como um estudioso e pesquisador do mundo natura I. $N$ este artigo, que utiliza a documenta çã o manuscrita do Instituto $H$ istórico e $G$ eográfico Brasileiro e do M useu Paulista da USP, será a nalisa da a atuação de José Bonifácio no processo da llustração portuguesa em quatro momentos: os estudos na Faculdade de Filosofia da Universidade de Coimbra, a entrada para a Academia Real das Ciências de Lisboa, a viagem científica pelos principais centros de mineração da Europa C entral e do $\mathrm{N}$ orte e a nomeação para o cargo de intendente geral das M inas e M etais do Reino. A análise da a tua ção do naturalista em sua fase portuguesa permite observar o papel ativo que os portugueses natura is do Brasil desempenharam no processo de difusã o das luzes pelo Reino luso. Instituto Histórico e G eográfico Brasieiro. M useu Paulista.

PA LAVRAS-ChAVE: José Bonifácio de Andrada e Silva. Universidade de Coimbra. História das ciências. Academia Real das C iências de Lisboa. Intendência G eral das M inas e M eta is do Reino.

ABSTRACT: José Bonifácio de Andrada e Silva's presence in historiography is nearly consensual, as far as his identification as the "Patriarch of the Independence" is concerned. This identification corresponds to the primacy a tributed to his status a s a sta tesman and parlia mentarian. How ever, 
he became known not only as a public man, but also as a man of learning, into researching the natural world. This article wich makes use of the IHG B and M P/ USP manuscripts colections, will investigate the role played by José Bonifácio in the process of the Portuguese Enlightenment in four moments: his studies at Coimbra University Law School, his admission to the Sciences Royal Academy in Lisbon, the scientific trip to the main mining centres in $\mathrm{C}$ entral and $\mathrm{N}$ orth Europe, and his appointment for the $G$ eneral Intendancy of the $M$ ines and $M$ etals of the Kingdom. The analysis of the naturalist in his Portuguese phase allows the observation of the active role the Brazilian-born Portuguese have played in the process of diffusion of the Enlightenment in the Portuguese Kingdom.

KEYW O RDS: José Bonifácio de Andrada e Silva. C oimbra University. History of Science. Lisbon Royal Academy of Science. $G$ eneral Department of $M$ ines and $M$ etals of the Kingdom.

0 propósito em prosseguir com os estudos em História das C iências no contexto do Império colonial português entre o fim do século XVIII e início do XIX encontra em José Bonifácio de Andrada e Silva um campo apropriado e perspectivas fecundas de trabalho. Isso porque, em primeiro lugar, sua presença na bibliografia especializada se faz, de forma quase que consensual, principalmente em to rno de sua identificação como o Patria rca da Independência, o que, grosso modo, corresponde ao seu perfil de estadista e parlamentar. Portanto, são análises que enfatizam o viés político de sua trajetória histórica.

$\mathrm{N} o$ entanto, José Bonifácio notabilizou-se não apenas como homem público, mas ta mb ém como na tura lista, estudioso e pesquisa dor do mundo na tura l. Ele participou de viagens de cunho científico, fo i sócio de inúmeras sociedades científicas européias, publicou diversas memórias no âmbito da História $\mathrm{N}$ atural e administrou espaços governamenta is portugueses ligados diretamente à mineração e à a gricultura. Portanto, em que pese a densidade da bibliografia a seu respeito, há lacunas que estimulam a reflexão em novas direções.

0 objetivo deste trabalho é resgatar o perfil de naturalista do personagem citado durante o período em que viveu em Portugal. Será a nalisada a sua a tuação no processo da llustração portuguesa em quatro momentos: os estudos na Faculdade de Filosofia da Universidade de Coimbra, a entrada para a Academia Real das Ciências de Lisboa, a viagem científica pelos principais centros de mineração da Europa C entral e do N orte e a nomeação para o cargo de intendente geral das M inas e M etais do Reino. A a nálise da a tuação do naturalista em sua fase portuguesa permite observar o papel ativo que os portugueses natura is do Brasil desempenharam no processo de difusão das luzes pelo Reino luso.

A formação científica de José Bonifácio na Universidade de Coimbra

José Bonifácio de Andrada e Silva nasceu em Santos em 1763. Era filho de D. Maria Bárbara da Silva e Bonifácio José de Andrada. Seu pai era 
um alto funcionário da Coroa, embora também tivesse outras atividades como 0 comércio e possuísse a segunda maior fortuna de Santos. Tinha outros irmãos, dentre os quais se notabilizaram as figuras de M artim Francisco e Antônio Carlos.

A instrução primária foi dada pela própria família, destacando-se nessa tarefa os seus tios padres, uma vez que as escolas primárias de Santos não tinham um ensino de tão boa qualidade. Juntamente com os seus dois irmãos citados, José Bonifácio foi para São Paulo, com o intuito de receber uma formação que extrapolasse aquela recebida no âmbito familiar. Em São Paulo, freqüentou o curso preparatório mantido por frei Manuel da Ressurreição, o que the possibilito u os primeiros conta tos com a cultura clássica. Ta mbém freqüentou aulas de $\mathrm{G}$ ramática, Retórica e Filosofia, matérias indispensá veis para quem planejava estudar em Coimbra ${ }^{1}$.

Em 1780, viajou para Portugal, matriculando-se na Universidade de Coimbra nos cursos de Direito $\mathrm{C}$ anônico e Filosofia $\mathrm{N}$ atural. Ainda na cidade de São Paulo, ele e os seus dois irmãos, todos membros da elite colonial, aproximaram-se das elites cultas da metrópole que lá estudavam e juntos leram as mesmas obras e receberam a mesma formação ${ }^{2}$.

José Bonifácio ingressou na Faculdade de Filosofia, criada no conjunto das reformas pombalinas com o objetivo de ensinar as C iências $\mathrm{N}$ a tura is e as C iências Físico-Q uímicas. Para enfrentar os quatro anos de curso, não havia aulas preparatórias, contava-se, no entanto, com os compêndios de Antonio $G$ enovese, C arl von Linné, Petrus van M usschenbroek e a História natural, de Plínio.

Durante o período em que esteve na universidade, José Bonifácio recebeu uma ampla formação. $\mathrm{N}$ a Faculdade de Direito, cursou as cadeiras de Direito $\mathrm{N}$ atural, História do Direito C ivil Romano e Português, Elementos de Direito Romano, Elementos de Direito $C$ anônico, Direito $C$ ivil Pátrio e Jurisprudência. Por sua vez, na Faculdade de Filosofia, cursou as cadeiras de História $\mathrm{N}$ atural, Física Experimental, Q uímica Teórica e Prática. E, na Faculdade de M atemática, freqüentou o curso de $\mathrm{G}$ eometria.

Foi, portanto, nesse espaço institucional que José Bonifácio recebeu o título de bacharel em Filosofia e Leis no dia 16 de julho de 1787, embora seu diploma só the fosse concedido em julho do ano seguinte, passando a integrar a "elite do conhecimento" formada pela instituição e que seria arregimentada para ocupar os principa is quadros do Estado Português ${ }^{3}$. Em função da sua titulação, optaremos por denominá-to como um filósofo na tural. Evitamos assim os anacronismos históricos já que a palavra cientista ainda não havia sido usada nesse momento ${ }^{4}$. Além disso, cabe registrar que foi como filósofo que ele próprio se auto-definiu em uma de suas notas:

Eu não sou partidarista da mitosofia ou da teosofia. Sou filósofo, isto é, constante indagador da verdadeira e útil sabedoria. Deixo aos Platônicos velhos e novos o seu Autoagathon; e procuro somente conhecer os homens, e as coisas pelo lado do seu uso prático para deles adquirir o conhecimento útil $\left.\right|^{5}$.

Além de ter assinalado essas duas características do moderno pensamento científico, o pragmatismo e o utilitarismo, José Bonifácio não
1. SOUSA, 1957.

2. SILVA, M.B. N., 1999.

3. DOMINGUES, 2000.

4. Optei por usar o termo filósofo natural para caracterizar o personagem estudado, uma vez que não havia sido empregado ainda o termo cientista nessa época. 0 termo cientista foi usado pela primeira vez em 1833 quando William Whew ell o aplicou em uma reunião da Associação Britânica para o Avanço da Ciência ao se referir às pessoas que ali se faziam presentes. Cf. BARNES, 1987.

5. ANDRADA E SILVA. Notas filosóficas... 
6. FERRONE, 1997

7. 0 período da Viradeira será compreendido como a expressão de uma dupla forma de se conceber a política. De um la do, observamos uma maneira de conceber a política fundada na reforma do aparelho de Estado, no domínio fiscal, militar ou da administração da justiça. Do outro, temos uma maneira baseada em dá divas liberais, mercês e na formação de laços pessoais ou clientelistas, política esta bem característica das sociedades do Antigo Regime. Seguindo essa perspectiva de se fazer política, o Estado era visto na lógica de uma série de nomeações, capazes de alimentar clientelas ou redes de interesses pessoais. 0 cargos eram obtidos não em função das qualidades da pessoa mas das amizades que ela construía e era capaz de cultivar. Havia um forte vínculo entre as compe tências técnicas e as relações de confiança. Cf CURTO, 1999.

8. NOVAIS, 1995; FALCON, 1989. mencionou uma terceira atitude que ta mbém estará presente em suas ações como estudioso e que complementa aquelas duas citadas, reforçando assim a modernidade do seu pensa mento: a atitude de identificar e classificar os elementos do mundo da natureza, sobretudo, os minerais.

C abe registrar que seguiremos a análise de Ferrone ${ }^{6}$ sobre 0 estudioso das ciências do século XVIII para a nalisarmos a a tuação de José Bonifácio de Andrada e Silva. Da mesma forma que os estudiosos que viviam nas sociedades do Ancien Régime, a carreira de José Bonifácio como filósofo foi caracterizada por encerrar-se completamente na fidelidade a uma espécie de dupla identidade.

Primeiro, observa-se a sua adesão ao modelo do homem de ciência organicamente ligado ao Estado, que aceitava por completo a lógica e os valores de uma sociedade hierarquizada, estabelecida, organizada por ordens e classes, e corpos diferenciados pelas dignidades, honras, onipresença do privilégio e categorias. 0 Estado atribuía ao estudioso das ciências honras e privilégios, conforme o costume e a lógica do Ancien Régime, privilégios que iam desde uma isenção parcial dos rendimentos a té a dispensa do serviço militar, a enorme possibilidade de ser levado à presença do rei, o recebimento de bolsas de estudo, a participação no cerimonial da Corte e nas manifestações públicas. o compromisso com o monarca e com o sistema de organização da vida intelectual assente no patronage permitia aliás desenvolver a fundo as potencialidades do método científico e aumentar o número dos protagonistas em virtude dos financiamentos, das pensões, dos privilégios a largados pelo soberano. 0 homem de ciência do século XVIII, no contexto do antigo regime, era basicamente um funcionário do Estado, cujas atividades eram financiadas pelos monarcas, revelando assim o pacto tácito com o poder.

Por outro lado, observa-se na prática científica do filósofo estudado a adesão e difusão do enciclopedismo, a ideologia científica do progresso, o utilitarismo e o pragmatismo, assim como a vontade e o desejo de classificar os elementos do mundo natural, traços que caracterizam o moderno pensamento científico. Ademais registremos o fato de ser membro da República das Letras, com os seus valores cosmopolitas, uma vez que participou ativamente de inúmeras sociedades científicas e publicou os trabalhos de suas pesquisas que seguiam 0 método moderno da observação e da experimentação. Uma dessas sociedades foi a Academia Real das Ciências de Lisboa, onde teve uma participação bastante ativa e publicou vários trabalhos científicos.

As memórias científicas apresentadas à Academia Real das C iências de Lisboa

0 ápice da llustração portuguesa ocorreu no momento em que assumiu o trono D. M aria I, dando início a o que se convencionou chamar de Viradeira?. Esse período caracterizou-se pelo reforço das práticas llustradas de caráter pragmático-científico, que já vinham sendo fomentadas desde o período do consulado pombalino, durante o reinado anterior de D. José $I^{8}$. 
0 absolutismo llustrado português do período do reina do de D. M aria e da regência do príncipe $D$. João mostrou que era capaz de criar formas específicas de ordenamento do mundo natural das colônias, como uma força econômica remobilizadora do Império colonial. Das "produções naturais da colônia" viria a fonte capaz de contribuir para a geração de riquezas que estimulariam a industrialização do Reino português.

Para atender às demandas reformistas de novo tipo, encaminhadas pelo poder régio, era necessária a a tuação de um grupo de intelectuais que servisse de âncora a tais demandas. 0 centro aglutinador do novo ideário reformista foi a Academia Real das C iências de Lisboa, locus do deba te científico e da gestão da política colonial voltada para a exploração do mundo natural. A instituição foi criada por iniciativa de D. João Carlos de Bragança, 20 duque de Lafões, tio de D. Maria I, que havia ficado ausente da nação lusa no governo pombalino e assim pôde observar o estado da ciência em outros países europeus, como a França e a Inglaterra. Ao regressar, considerou de extrema importância a necessidade de se criar uma Academia de Ciências como havia naqueles países - a Royal Society (1662), em Londres, e a Academie Royale des Sciences (1666), em Paris - para que se fomentasse a cultura científica em Portugal. 0 plano de criação da academia e os seus estatutos foram elaborados em conjunto pelo duque de Lafões e pelo naturalista abade José Correia da Serra, outro que estivera fora no governo pombalino, e apresentados à D. Maria I, que deu parecer favorável a 24 de dezembro de 1779. A rainha tornar-se-ia, em 1783, a protetora da academia, que seria o centro do debate intelectual, a ssim como 0 mundo da política de Q ueluz, espaço das tensões das intrigas dinásticas entre os absolutistas e de onde partiam as ordens régias para todo o Império colonial português, substituindo a "utopia pombalina da reconstrução de N ossa Senhora da Ajuda" ${ }^{\prime}$. No dia 4 de março de 1789 , José Bonifácio, conduzido pelas mãos do duque de lafões, ingressou na academia.

A academia estava dividida em três classes, duas de Ciências (C iências da O bservação - M eteorologia, Q uímica, Anatomia, Botânica e História N a tural - e Ciências do Cálculo - A ritmética, Álgebra, G eometria, M ecânica e Astronomia) e uma de Belas-Letras, que deveria dedicar-se ao estudo dos vários ramos da Literatura portuguesa. Cada uma das classes tinha oito sócios efetivos, a lém dos sócios supranumerá rios, honorários e correspondentes. Tinha um observa tório matemático, um laboratório químico e dois museus de história natural, ou seja, espaços voltados para pesquisas no campo da História $\mathrm{N}$ atural baseadas na observação e experimentação.

o corpo acadêmico era constituído por um grande número de associados, de várias orientações e ofícios, como reis, clérigos, na turalistas, proprietários de terras, ministros, professores e habitantes de várias colônias ultramarinas, devendo a ssim a academia ser compreendida não de uma maneira uniforme e coesa, mas como uma agremiação que resultou de uma série de correntes ou estilos de pensamento. Contudo, um elemento lhe era comum: o projeto de escla recimento da sociedade portuguesa, a necessidade de instruir sua população e divulgar, entre os vários estratos sociais, os conhecimentos científicos.
9. MUNTEAL FILHO, 1998. 
10. NOVAIS, 1984, p. 108.

11. FALCÃO, 1963, v. 1, p. 48.

12. Entendo a palavra crise no sentido exposto pelo historiador. Cf. NO VAIS, 1995.
N esse espaço, ganhou destaque o paduano Domenico Vandelli, que adoto 0 ecletismo do reformismo llustrado, colocando-o a favor de algumas id éias mercantilistas, incorporando tanto os princípios fisiocráticos italianos e franceses como os da economia clássica ing lesa ${ }^{10}$. Vandelli defendia a realização de um profundo inventário da natureza nas colônias, natureza essa que seria estudada nos estabelecimentos cient́ficos, como os jardins botânicos, museus de história natural, entre outros, por meio dos métodos de classificação e dissecação. Por outro lado, o conhecimento da natureza estava diretamente relacionado à política fomentista do governo mariano e joanino, uma vez que se acreditava que as produções natura is da colônia ajudariam na recuperação econômica do Reino, valorizando-se assim a agricultura baseada nas práticas científicas de orientação pragmática, que viam na natureza tropical uma fonte geradora de riqueza. A natureza colonial deveria ser cientificamente conhecida e explorada, pois contribuiria para o processo de industria lização portuguesa.

A academia publicava as memórias, estimulando e promovendo a produção intelectual nos mais variados campos, como a Mineralogia, a Agricultura, a Economia, assim como estudos que tratavam de produtos natura is, como o algodão, a oliveira, a vinha, as castanheiras, os carvalhos, entre outros. Por meio das memórias, foi realizado um verdadeiro levantamento da natureza do Reino e da colônia com o objetivo de saber qua is os usos que as produções natura is poderiam oferecer à nação portuguesa e contribuir para o seu processo de industrialização.

$N$ esse espaço de discussão cient́fica e sociabilidade intelectual, o filósofo na tural José Bonifácio publicou diversas memórias científicas, por meio das quais, ele colocou a ciência como algo que pudesse ser útil à sociedade do Império colonial português. Por ciência útil devemos entender o conjunto de matérias que possibilitariam a solução ou a transformação da realidade vivida. Ele acreditava que o papel da ciência não se restringia ao processo de conhecimento, e sim o transcendia pois tinha o poder de transformara sociedade. Ele procurava tornar público os conhecimentos sobre o combate às doenças, a introdução de novos cultivos, a diminuição do custo de certos produtos, a preservação da natureza, etc.

Em seus trabalhos cient́ficos, a ciência tem como função social resolver problemas. A utilidade é a vértebra da sua concepção de ciência, a qual se encontra a serviço do homem e do lugar onde ele vive. Para ele, a ciência é prática, aplicada, deve ajudar a resolver os males sociais. Como dizia o próprio Bonifácio,"se das minhas idéias se quiser tirar proveito, folgarei infinito de ser útil"11.

A intensa difusão de conhecimentos científicos que há na obra de José Bonifácio deve ser entendida como um verdadeiro planejamento racional de ações voltadas para o futuro e de projetos prospectivos baseados em análises históricas sistematizadas e a tua lizadas. As memórias publicadas eram parte de um planejamento estatal para a superação da crise ${ }^{12}$, o que mostra uma tomada de consciência pelo autor da situação em que Portugal se encontrava no momento e o que justifica a a ná lise particular de cada uma das memórias da fase portuguesa 
de José Bonifácio, onde se observa como o econômico, o político e o científico são indissociáveis.

Em uma nota ele reafirmou a necessidade da aplicação do conhecimento científico em prol da sociedade:

Desde que eu comecei a pensar que as ciências eram um emérito fútil quando não se aplicavam a o bem público, não pude deixar de espantar-me vendo o desleixo dos sábios e 0 pouco caso que faziam do bem público ${ }^{13}$.

Essa preocupação com a utilidade da ciência, ou melhor, o conhecimento cient́fico destinado para o uso e a perfeiçoamento da humanidade, mostra a presença das idéias baconianas nas memórias escritas por Bonifácio. Portanto, o filósofo estudado mostrava-se conectado ao moderno pensamento científico, uma vez que buscava tornar o conhecimento prático e útil.

Ao propor uma ciência geradora de utilidades à sociedade, contribuindo para solucionar os problemas que nela existam, acreditamos que ele partilhava da utopia do pensamento llustrado, no qual o conhecimento cient́fico deveria contribuir para o aperfeiçoamento das sociedades, tornandoas melhores e perfeita $\mathrm{s}^{14}$.

A divulgação das suas pesquisas científicas em memórias, a na is, revistas, periódicos, boletins, etc. mostra de forma clara no pensamento de José Bonifácio a presença do ideal ilustrado de "esclarecimento", a função "educadora" que os sábios e os letrados deveriam cumprir na sociedade.

Em suas memórias científicas, o principal objeto de estudo é a natureza. Para conhecê-la, Bonifácio a submetia à observação e à experimentação. A natureza era a sua grande aliada na luta contra o conhecimento revelado. Ele buscava encontrar no mundo natural os princípios que regiam o mundo dos homens. Procurava extraír-lhe o segredo, submetê-lo à luz do entendimento e penetrá-to com os poderes do espírito. A natureza seria o locus perfeito para 0 exercício da sensibilidade e da razão.

José Bonifácio estudava os três reinos do mundo natural - animal, vegetal e mineral. Por meio de suas características intrínsecas, identificava, classificava e ordenava cada espécie de acordo com a sistematização taxionômica. Ele partia da observação detalhada dos fatos para estabelecer a classificação, encontrando assim na natureza as suas próprias leis.

Em suas memórias, transparece uma perspectiva otimista oriunda dos elementos do mundo natural. As produções da natureza eram vistas como uma fonte de conhecimento mas também de riquezas, na medida em que seriam capazes de gerar lucros para a Coroa portuguesa. Era, portanto, uma natureza encarada de forma quase divina, como produtora de riquezas e como mestra da própria vida ${ }^{15}$. Esse ponto expressa a visão de mundo de José Bonifácio que centra no domínio da natureza - capaz de gerar riquezas, e, portanto, deve ser cientificamente conhecida e explorada - a alternativa para a recuperação do Reino português e do "Brasil".
13. ANDRADA E SILVA. Notas sobre o alambique.

14. MANUEL, 1979

15. KURY, MUNTEAL FILHO, 1995. 
16. Sobre esse subgrupo de vertente utilitarista e naturalista ver MUNTEAL FILHO, 1993. Para além de Vandelli, um dos sócios fundadores da academia, o subgrupo era composto por outros ita lianos como Michele Franzini, João Antonio Dalla Bella, Michel Ciera, Giovani Angelo Brunelli e Luigi Cicchi. Quanto aos naturalistas do Reino ou coloniais que atuaram no citado subgrupo estavam: João Antonio Monteiro, José Correa da Serra, Luís Ferrari de Mordau, João de Loureiro, Baltazar da Silva Lisboa Joaquim de Amorim Castro, Joaquim Velloso de Miranda, José Mariano da Conceição Velloso, Jero nimo Joaquim de Figuei redo, João da Silva Feijó, José da CostaAzevedo,José Pinheiro de Freitas Soares, Manuel Arruda da Câmara e José Bonifácio de Andrada e Silva.

17. Vandelli deu uma grande contribuição para a difusão das ciências naturais em Portugal. Ele manteve uma ativa relação epistolar com mais de 40 personalidades de 11 nacionalidades (Carl von Lineu, Antoine Lau rent de Jussieu, Antoine Gouin, Joseph Blanks, entre outros) e com várias instituições científicas internacionais (Real Jardim Botânico de Madri; Jar dim do Rei e Sociedade Real de Agricultura, em Paris; Jardim Real de Kew e Royal Society, em Londres, etc.). Essa internacionalização das relações científicas não pode ser omitida quando avaliados os contributos nacio nais para a formação do campo disciplinar da His tória Natural setecentis ta.Vandelli contribuiu para alargar a circulação e divulgação de instrumen-
Essa visão de mundo nos permite relacionar o pensamento de José Bonifácio a o subgrupo llustrado utilitarista e natura lista ${ }^{16}$ da Academia Real das Ciências de Lisboa, que tinha em Domenico Vandelli ${ }^{17}$ a sua figura máxima. A produção científica llustrada de base naturalista propôs soluções para vencer a crise econômica do Império colonial português. Entre essas soluções priorizavase um melhor a proveitamento das produções natura is das colônias, sobretudo do Brasil. Essas propostas estavam baseadas principalmente na idéia de que a política fomentista da Coroa portuguesa iniciada no período pombalino deveria ser intensificada e na valorização da agricultura, fundamentada nas práticas cient́ficas de orientação pragmática ${ }^{18}$.

A visão de mundo do subgrupo de naturalistas liderado por Vandelli e partilhada por José Bonifácio mostra o grau de tomada de consciência durante a crise econômica e financeira em que a nação lusa se encontrava no fim da governação pombalina.

$\mathrm{N}$ as memórias de José Bonifácio encontramos propostas para superar a crise. Um dos traba lhos científicos a presenta dos por José Bonifácio na A cademia de Ciências foi o Parecer sobre o método de desinfetar as cartas vindas de países estrangeiros. A realização de tal pesquisa ocorreu em função do Aviso de 19 de setembro de 1814 expedido pela Secretaria de Estado dos N egócios da Guerra e da Marinha. $N$ esse aviso, o monarca português pediu à Academia Real das C iências o seu parecer sobre o método que deveria ser seguido para desinfetar as cartas vindas de países estrang eiros"contagiados ou suspeitos de peste, ou de febre amarela".

Para tal investigação, a academia nomeou uma comissão de três dos seus sócios: José Bonifácio de Andrada e Silva, Luiz de Siqueira 0 liva (que não teve a honra de assinar o parecer, uma vez que havia falecido dias antes) e Francisco Elias Rodrigues da Silveira ${ }^{19}$.

0 parecer nunca foi publicado. A comissão julgou dispensável fazer uma dissertação "miúda e científica, para expender e corroborar o seu voto". Contudo, garantiam que aquele era o resultado de "maduros e longos exames baseados em princípios e experiências". 0 parecer final foi dado pela Secretaria da Academia Real das Ciências de Lisboa no dia 8 de julho de 1815.

A pesquisa sobre o método de desinfetar as cartas vindas de fora está inserida num debate científico iniciado em 1813 por C harles Stuart, ministro da C oroa britânica em Lisboa, que recla mou a substituição do méto do desinfetante em vigor por novas técnicas que materializassem o poder da nova química, dispensando assim a abertura das cartas. 0 método desinfetante que vinha sendo aplicado à correspondência seguia as disposições do Regimento do Porto de Belém e do denominado Regimento da Peste, ambos publicados em 1695, e que envolviam o indesejável pré-requisito de abertura e desdobramento das cartas. A discórdia, que começou por dividir os membros da Junta de Saúde Pública, cedo se estenderia à Academia de Ciências, culminando por fim nas páginas do Jornal de Coimbra ${ }^{20}$.

$\mathrm{N}$ esse parecer, a comissão analisou dois pontos: primeiro, se era necessário abrir as cartas vindas de países estrangeiros e passá-las por vinagre 
para serem desinfetadas; segundo, se as cartas poderiam ser desinfetadas sem serem abertas por meio de alguma fumigação que evitasse o contágio e qual deveria ser essa fumigação.

Sobre o primeiro ponto, a comissão não negou a utilidade da antiga prática dos lazaretos, que se serviam de vinag re (ácido a cético) como desinfetante das cartas, seguindo assim as idéias de Morveau (G uyton de Morveau - 1737 $1816)$ que aprovava o uso do ácido acético. Contudo, os estudiosos argumentaram que a $Q$ uímica moderna, ou seja, a quela que seguia os princípios de Lavoisier, havia descoberto ácidos mais poderosos e ativos, e, portanto, não havia motivo para o uso exclusivo do vina gre. Eles consideraram que tal substância a o ser passada nas cartas tinha o inconveniente de progressivamente perder a sua virtude, reduzindo-se a "um fleugma inativo e sem préstimo".

Por existir, então, ácidos mais poderosos que o vinagre que penetravam as cartas em fumigações sem que elas fossem abertas, não era necessá rio abrilas nem molhá-la s em vina gre. Em função disso, julga ram tal méto do desnecessá rio e inconveniente.

Antes de passarmos diretamente para o segundo ponto, cabe destacar a idéia de contágio presente no início do século XIX. O conceito básico de contágio era o de transmissão de uma doença a partir de estímulos provenientes do mundo externo e do conta to de uma pessoa doente com a outra. Admitia-se o contágio pelo contato direto, pelo ar e por objetos materiais (roupas, móveis, cartas, etc.) que servissem de intermediários. A noção de contágio associa va a doença ao contato e ao sentido do ta to e do olfato. $\mathrm{N}$ ão se imaginava até esse momento que pudesse haver transmissão de enfermidades, por exemplo, pela á gua ou por um a gente microbiológico. Somente com o aparecimento do conceito de transmissão foi que a propagação das epidemias se deslocou dos imprecisos sentidos do olfato e do ta to para o da visão ${ }^{21}$.

As práticas de desinfecção e de fumigação, como por exemplo, a de desinfetar as cartas vindas de países estrangeiros que pudessem estar contagiadas por pestes, estavam relacionadas à idéia do contá gio. 0 receptor, antes de abrir a carta, deveria ter o cuidado primeiro de desinfetá-la, neutra lizando com um anti-séptico o possível miasma. Essa era uma típica a titude da concepção de que as enfermidades eram adquiridas via os sentidos, não tendo uma correspondência no corpo nem sendo identificadas como lesão em um órgã $0^{22}$.

Q uanto ao segundo ponto, ou seja, a veriguar a possibilidade de desinfetar as cartas por alguma fumigação que evitasse o contá gio sem serem abertas, e qual deveria ser essa fumigação, fa to que já havia ficado em parte respondido, a comissão a crescentou algumas observações.

A primeira dizia respeito a o fato de que os gases sulfuroso, muriático e oximuriático, quando a tra vessa vam as cartas fechadas, altera vam as letras, sobretudo quando elas eram expostas por algum tempo em a parelho próprio aos seus vapores. 0 ra, se isso sucedia com cartas fechadas, as mesmas a 0 serem golpeadas produziriam gases, o que não deveria ser feito para maior segurança, como propuseram os integrantes da comissão. Q ualquer, pois, que fosse o gás dentre os citados a ser usado, como todos eram desinfetantes e tos intelectuais do conhecimento (intercâmbio de produtos naturais e artificiais, pareceres científicos sobre temas e publicações de História Natural, notícias sobre as atividades de museus e jardins botânicos) e objetos naturais exóticos imprescindíveis à construção do Grande Catálogo da N atureza e à afirmação de novos paradigmas disciplinares. Cf. BRIGOLA, 2003.

18. MUNTEAL FILHO, 1998.

19. ANDRADA E SILVA; SILVEIRA, 1814.

20. DUARTE; DIAS, 2001, p. 431.

21. CZRESNIA, 1997.

22. Ibid., p. 59 
penetrantes, ficava claro, que qualquer um deles era próprio para o fim, sem ser preciso romper o sigilo das cartas nem molhar o papel.

Em segundo lugar, a comissão a rgumento u que as carta s não eram suscetíveis de conservar com vigor os"miasmas pútridos contagiosos", e caso os conservassem, muito pequeno deveria ser o número dessas partículas, e a sua força, podendo pois ser destruída por qualquer gás ácido. Em função dessa a verigua ção, os sócios que compunham a comissão concluíram não ter sido propagada "peste do levante ou febre amarela "por meio das cartas.

Cabe mencionar que essa preocupação em descobrir meios que pudessem combater os efeitos nocivos dos miasmas era uma preocupação recorrente no século XVIII. A teoria dos miasmas explicava não apenas as enfermidades dos pântanos, mas também as doenças produzidas por cheiros de coisas estragadas e em putrefação. A malignidade do ar provinha de emanações pútridas ${ }^{23}$. N o final do Setecentos, as idéias sobre miasmas e sobre a transmissão de enfermidades pelo ar deixaram de ser apenas hipóteses. A idéia de que o ar poderia conter substâncias maléficas ganhou apoio nesse momento. Foram descobertas novas substâncias capazes de impedir a putrefa ção e que deviam ser também capazes de destruir os miasmas. Entre os estudiosos dos chamados anti-sépticos estavam Louis Bernard e G uyton de Morveau, este último companheiro de pesquisas de Lavoisier, que estudou ácidos minerais em forma gasosa e recomendava o ácido muriático oxigena do como meio de destruir os vapores nocivos.

Entre os gases anti-sépticos o mais poderoso, segundo os membros da comissão, era o gás oximuriático, por ser considerado o ma is comburente e além disso o mais expansivo e elástico, podendo em brevíssimo tempo encher grandes espaços, sobretudo quando a gia seco e concentrado. Como os miasmas da peste e da febre amarela eram substâncias combustíveis, deveriam ser destruídas por tal gás. 0 mesmo comprovava a prática de mandar queimar to das as coisas e ma téria sinfectadas para se evitar a difusão de qualquer moléstia contagiosa. Esses fatos levaram os membros da comissão a se interrogarem sobre 0 uso efetivo do vinagre como um anti-séptico e a preferir o gás oximuriático, uma substância da Q uímica moderna.

O s membros da comissão concluíram que o gás oximuriático era 0 ma is poderoso desinfetante conhecido, concordando assim com M orveau. Por isso, eles julgaram que em todos os casos em que houvesse certeza de peste ou febre amarela violenta sempre deveria ser usado esse gás em preferência a qualquer outro, ainda mesmo para a desinfecção das cartas. Para os casos menos a rriscados, julgaram que as fumigações propostas pelo Dr. Bernardino Antonio $\mathrm{G}$ omes resolveriam o problema, havendo porém a precaução de golpear as cartas pelos lados, para que melhor e mais depressa pudessem ser penetradas por a queles vapores, sem alterar a escrita.

Cabe registrar que nesse parecer os nomes dos ácidos em forma de gases seguia a nova nomenclatura química estabelecida por Lavoisier. Eles usaram gás sulfuroso, muriático e oximuriático. A terminologia muriático foi estabelecida no Método de nomenclatura química (1787), obra coletiva 
elaborada por Lavoisier, Berthollet, Morveau e Fourcroy, para substituir o ácido de sal marino,também chamado espírito de sal ${ }^{24}$.

Vale ressaltar que o gás muriático, hoje cloreto de hidrogênio, foi objeto de grande controvérsia após a morte de Antoine Laurent Lavoisier (17431794). Ele tem propriedades ácidas e reage violentamente com a água, originando uma solução muito ácida, o ácido muriático (hoje ácido clorídico). 0 ra, nem o gás muriático nem o ácido dele resultante contém oxigênio, como acreditava o químico francês. 0 s químicos que sucederam a Lavoisier tentaram descobrir tal elemento químico nesses compostos, mas foi em vão. A pós vários debates, concluiu-se que nem todos os ácidos continham oxigênio ${ }^{25}$.

Poucos anos separavam a elaboração desse parecer pela comissão constituída pelos três sócios da academia e a descoberta por H. Davy, em 1808 , de que o ácido muriático oxigenado era uma substância elementar que recebeu o nome de cloro. Por isso, seria incorreto considerá-los a fastados das principa is transforma ções que vinha ocorrendo no campo da $Q$ uímica, pois esse era um momento de transição entre a velha e a nova $Q$ uímica.

A maior parte das memórias científicas apresentadas à Academia Real das C iências de Lisboa por Bonifácio estava centrada nos estudos sobre a mineralogia, o que já a pontava para uma especialização da atividade científica do personagem. Contudo, outros temas também ocuparam as páginas de suas dissertações, deixando transparecer o saber enciclopédico do estudioso. No dizer de um de seus biógrafos, foi o espaço da Academia Real das Ciências de lisboa que"lhe abriria os caminhos de uma carreira de filósofo e the traria a glória e muitas decepções, o puro gozo intelectual e to das as matérias reservadas aos que excedem a carreira comum"26.

"Adquirindo os modernos conhecimentos mineralógicos":

A viagem científica pela Europa Central e do N orte

Logo que entrou para a academia, sob a proteção do duque de Lafões, José Bonifácio foi nomeado para a realização de uma viagem científica por diversos países europeus com M a nuel Ferreira da Câmara Bethencourt e Sá e Joaquim Pedro Fragoso. Para a realização desse empreendimento, o ministro Luiz Pinto de Souza baixou minuciosa instrução para a realização da viagem de aperfeiçoamento técnico a tra vés da Europa $(31 / 5 / 1790)^{27}$. N essa instrução foi determinado que M anuel Ferreira da Câmara seria o "chefe de Brigada", sendo responsável pela "decisão do tempo dos estudos e das viagens, do destino de cada um dos sócios, e dos sítios aonde [sic] deviam empregar-se"28.

0 recebimento da bolsa de estudos para a realização da viagem oferecida pelo governo português nos permite afirmar que Jo sé Bonifácio acabava por inserir-se na lógica do prestígio, na medida em que vivia sob a proteção do Estado (por meio de cargos, pensões, mesadas, etc.). Ao viver literalmente às custas da Coroa portuguesa, passava a ter uma posição privilegiada em sua
24. BENSAUDE-VINCENT: STENGERS, 1996.

25. Ibid., p. 128-131.

26. SOUSA, 1957

27. A viagem será analisada por nós levando em consideração a sua importância para a especialização científica do personagem. Sobre os seus aspectos políticos ver SILVA,A. R. C, 1999.

28. FALCÃO, 1963, v. 3, p. 169. 
29. ELIAS, 1995.

30. FALCÃO, 1963, v. 3 , p. 170

31. BENSAUDE-VINCENT STENGERS, 1996

32. FALCÃO, 1963, v. 3 , p. 172

33. ARLET, 1991

34. ANDRADA E SILVA Diário de despesas.

35. O periódico Annales de Chimie foi criado no ano de 1787 de forma co letiva por Lavoisier, Morveau, Métherie, Gaspard Monge, Berthollet, Four croy, Hassenfratz e Adet. O novo periódico aju daria a difundir os princí pios da "nova" Química por meio das memórias que fossem publicadas. Cf.BENSAUDE-VINCENT STENGERS,1996. sociedade. Depender da C oroa significava proximidade e, portanto, participação em sua vida ${ }^{29}$.

$\mathrm{N}$ a instrução vinham determinados os locais por onde os filósofos deveriam passar. 0 percurso, longe de ser delineado arbitrariamente, era estipulado pelo poder administrativo. 0 grupo de viajantes contaria com uma ampla rede de diplomatas por todos os locais que visitassem, facilitando a entrada e permanência nos países estipulados pelo poder régio.

Primeiramente, deveriam ir à França, país expoente da llustração européia, palco da chamada Revolução Q uímica, liderada por Antoine Laurent Lavoisier, e centro onde se desenvolveu a Escola de M ineralogia Cristalográfica que teve como expoentes Romé de L'Isle e 0 abade René-Just Haüy. Em Paris, deveriam fazer um curso completo de Q uímica com Fourcroy (Antoine François de Fourcroy - 1755-1809) e outro de M ineralogia Docimástica com Le Sage (Balthazar-G eorges Sage - 1740-1824).

José Bonifácio frequentou o curso de Fourcroy, pois recebeu um certificado que atesta a sua presença em um"curso particular de M ineralogia e Q uímica em meu laboratório [Fourcroy ]"30. Ao cursar as aulas desse importante químico francês, o filósofo natural português entrava em contato com as principa is idéias da Revolução Q uímica, uma vez que Fourcroy colaborou para a formulação da "nova" nomenclatura química elaborada pelo grupo liderado por Lavoisier".

Por sua vez, o curso de Mineralogia programado para ser feito com o professor Le Sage não foi realizado com ele, mas com o professor Duhamel (G uillot-Duhamel), na Escola de M inas de Paris ${ }^{32}$. Se tivesse feito o curso de Le Sage, José Bonifácio teria estudado a Mineralogia Docimástica, área de especialização do estudioso francês. 0 curso que Duhamel oferecido na Escola de M inas estava relacionado a "a arte do minerador, a arte do metalurgista, a geometria elementar subterrânea, teórica e prática, ou o tratado dos filões ou veios mineralógicos e sua disposição pelo seio da terra" ${ }^{133}$

N o seu Diário de despesas e lições na cidade de Paris, que se encontra no Instituto Histórico e G eográfico Brasileiro (IHG B), em estado bastante precário, na página 13, aparecem as lições que tomou de Fourcroy, na área da Q uímica:

\section{Lição de Fourcroy}

Cânhamo macho em eflorescência dá muito pólen, solve o muriático oxigenado converte-se em cera...

Exoedros... redondos, peloso fica em estado mole.

A cera do Brasil, mais mole não ficará tão quebradiça pelo ácido do muriático oxigenado. Experiência do cobre fundidos em cera fundida, tira num instante ${ }^{34}$

Em Paris, foi admitido como membro correspondente da Sociedade Filomática de Paris, em sessão de 29 de janeiro de 1791, da qual era presidente Alexandre Brogniart (1770-1847). Por sua vez, a 4/3/1791, foi admitido como membro da Sociedade de História $\mathrm{N}$ atural de Paris, onde apresentou a Memória sobre os diamantes do Brasil, publicada pela primeira vez no ano de 1792, nos Annales de Chimie ${ }^{35}$, da citada sociedade. Uma versão inglesa desse 
mesmo artigo foi publicada no a no de 1797, no Journal of $N$ atural, Philosophy, Chemistry and Arts, de Londres.

Essa M emória está inserida em uma das tradições da mineralogia do século XVIII denominada de cristalografia, que tinha como fim a identificação, descrição e classificação dos cristais, a lém de estudar a sua estrutura e formação. O s estudos cristalo gráficos desenvolveram-se mantendo fortes liga çõ es com a Q uímica, uma vez que o mineralogista retirava-se para o laboratório, realizando as a nálises químicas das espécies para descobrir a sua verdadeira natureza. A cristalografia, no fim do século XVIII, herdou algumas características dos trabalhos de classificação natural dos minerais. Entre os principais expoentes da escola de mineralogia cristalográfica estavamo abade René-Just Haüy e Romé de L’Isle ${ }^{36}$.

José Bonifácio a presentou as várias formas de diamantes existentes no "Brasil", fazendo a sua descrição cristalo gráfica. Havia crista is de hábitos octaédricos, formados pela "união de duas pirâmides tetraédricas", o modelo clássico adamas octaedrus turbinatus, de Johann Gottschalk W allerius, ou o diamante octaedro de Romé de L'Isle. Havia ainda os crista is que se encontravam quase sempre nas encostas das montanhas, apresentando uma forma a rredondada, "faces curvas" e outros arredondados por "ondulação". Alguns diamantes exibiam hábitos cúbicos e identificavam-se a o adamas hexaedrus tabellatus, de W allerius.

Ao identificar cristalograficamente as produções diamantíferas, Bonifácio fez uso de dois sistemas: o de Johann G ottschalk W allerius e o de Romé de L'Isle. 0 sistema de classificação do primeiro baseava-se no uso do critério químico para a divisão dos minera is, distinguindo as suas características internas e externas. 0 s caracteres externos que permitiriam a classificação eram as propriedades físicas (a cor, a forma, o gosto, o cheiro) os usos e a ocorrência. $\mathrm{C}$ a so essas características fo rnecessem um quad ro inco mpleto e incerto, utiliza va $\mathrm{m}$ se então as a nálises química $\mathrm{s}^{37}$.

Por sua vez, o sistema de classificação de Romé de L'Isle baseava-se nos aspectos formais do sistema de classifica ção proposto por lineu, ou seja, 0 uso da forma do cristal para classificação e a insistência na hierarquia das classes minerais. No seu Ensaio de cristalografia (1772), Romé de L'Isle argumento u que os cristais foram ordenados de acordo com a sua forma e encadeados juntos em grupos de formas secundárias derivadas daquelas primárias por meio de partições imaginárias. Ele afirmou que os cristais eram compostos por pequenas "moléculas integrantes" salinas, compostas por "moléculas constituintes" ácidas e alcalinas. Cada mineral possuía uma estrutura e uma composição fixadas. Portanto, as classes minerais entã o necessárias para a taxonomia lineana foram mantida $s^{38}$.

0 uso de sistemas de classificação tão distintos na prática científica de José Bonifácio de Andrada e Silva não era apanágio apenas desse filósofo natural. José Vieira Couto, outro estudioso da filosofia natural, em sua prática científica de classificação dos minerais também utilizava diversos sistema $\mathrm{s}^{39}$. Essa tendência pode ser explicada pela formação de ambos personagens na
36. HOOYKAAS, 1994.

37 GUNTAU, 1997.

38 HOOYKAAS, 1994; LAUDAN, 1987.

39. SILVA, 2002. 
40. FALCÃO, 1963, v. 3, p. 173.

41. Ibid., p. 176.

42. RUDWICK, 1997.

43. Ibid.

44. ELLEMBERGER, 1994

45. Apud LAUDAN, 1987, p. 88 .
Universidade de Coimbra, espaço que se caracterizava por a presentar um enfoque eclético e pragmático.

Da mesma forma que Couto, também um estudioso da M ineralogia, José Bonifácio foi aluno do paduano Domenico Vandelli, primeiro lente de $\mathrm{Q}$ uímica da Universidade de Coimbra e ta mbém de $\mathrm{H}$ istória $\mathrm{N}$ atural, assim como principal expoente do subgrupo de naturalistas da Academia Real das C iências de Lisboa. $\mathrm{N}$ as cadeiras em que lecionava na Universidade de Coimbra, Vandelli seguia 0 método de lineu.

Após o período na França, os filósofos dirigiram-se, seguindo a instrução, para Freiberg, na Saxônia, que era o centro mais avançado em mineração da Europa e estudos correlatos e possuía a primeira academia de minas do mundo, a Bergakademie Freiberg. Deveriam, assim, freqüentar o curso de M inas desse distrito e assentar no local "praça de mineiros, para adquirirem todos os conhecimentos práticos". Lá, ambos receberam autorização da Superintendência das M inas para seguirem pelas "obras de mineração e as instalações de depuração e lavagem a elas pertencentes" ${ }^{40}$, bem como para José Bonifácio assistir ao curso de 0 rictognosia e $\mathrm{G}$ eognosia ministra do pelo professor Abraham $\mathrm{G}$ ottlob W erner, de quem se tornaria discípulo ${ }^{41}$.

A G eognosia (literalmente, conhecimento da terra) era o campo da mineralogia relativo à classificação das massas das rochas e suas relações espaciais. $0 \mathrm{~s}$ geognostas, como eles próprios se chamavam, tentavam definir e descrever as formações que seriam reconhecidas para além de uma simples região, alcançando escalas globais. A tarefa de reconhecer formações em diferentes regiões, tornando a classificação tão a plicável quanto fosse possível, foi tentada empiricamente por diferentes critério $\mathrm{s}^{42}$.

A $G$ eognosia expressou em primeiro lugar uma concepção estrutural da ciência mineral. Ela foi essencialmente uma ciência espacial, uma extensão tridimensional da geografia minera ${ }^{43}$. Abraham $\mathrm{G}$ ottlob W erner foi, sem dúvida, o responsável pela institucionalização dessa ciência, porém não foi o seu criador, uma vez que ela era o resultado científico de um saber muito mais antigo da Europa C entral e Suécia, já tendo outros autores anteriormente usado a expressão em suas publicações ${ }^{44}$.

Para W erner, a $\mathrm{G}$ eognosia era uma subdivisão da mineralogia. Ela distinguia-se da mineralogia geográfica, que estudava a distribuição das rochas e dos minerais pela superfície, e da 0 rictognosia, que era o conhecimento das substâncias fósseis do subsolo. 0 termo foi assim definido por ele:

$[\ldots]$ is that part of mineralogy which acquaints us systematically and tho roughly will the solid earth, that is, with its relationship to those natural bodies that surround it and which a re familiar to us, and also especially, with the circumstances of its external and internal formation and the minerals of which it consists according to their differences and mode of formation ${ }^{45}$.

Esse geognosta, formado pela Bergakademie de Freiberg e professor na mesma, considerava de fundamental importância a classificação e a nomeação dos terrenos segundo a sua ordem de sobreposição, pois dessa forma era possível informar aos mineiros a estrutura do subsolo e traduzir a idade relativa das 
camadas. $\mathrm{N}$ a sua publicação fundamental intitulada Kurze Klassifikation und Beschreibung der Verschiedenen $G$ ebirgsarten, esb oçou um esquema estra tigráfico que considerava aplicável à Terra. Ele argumentou que as camadas foram revolvidas após a sua deposição, e, em função disso, distinguia quatro forma ções (G ebirde): primitiva (Urgebirge); terreno estratifica do do Permicário, Triássico, Jurássico, C retáceo e Terciário (Flötzgebirge), terrenos a luviais (A ufgeschw emmte $G$ ebirge); camadas vulcânicas (Vulkanische $G$ esteine). Entre as duas primeiras classes, foram acrescentadas mais tarde, as formações de transição (Übergangsgebirge $)^{46}$.

Uma vez formado em Freiberg, José Bonifácio partiu em direção a outras regiões de minas da Saxônia e Boêmia. Em sua visita à cidade de Berlim, na Prússia, foi admitido como membro da Sociedade dos Amigos da N atureza de Berlim no dia 17 de janeiro de 1797. A seguir, foi em direção à Hungria, pois recebeu a utorização para visitar as minas e usinas metalúrgicas loca is ${ }^{47}$. Por sua vez, na Áustria, esteve, na Caríntia e Estíria, e visitou as salinas de $\mathrm{G}$ münden.

Partiram depois para várias regiões da Itália ${ }^{48}$ onde José Bonifácio fez importantes contatos científicos, como por exemplo com o físico Alexandre Volta, em Pá via, na Província de Turim, na Itália. A o visitar as M ontanhas Euga nei, no sul de Pádua, escreveu uma memória lida na Academia Real das Ciências de Lisboa, dissertação esta que se encontra a tualmente perdida, sobre a sua viagem geognóstica aos M ontes Eugâneos. N essa memória, Andrada seguiu as idéias netunistas do geognosta alemão W erner, que afirmava que a á gua dos mares era o agente principal da formação da crosta terrestre, em contraposição a o escocês Ja mes Hutton, defensor da teoria científica denominada plutonista que enfatizava a ação interna como a responsável pela formação das rochas. A opção do filósofo pelas idéias netunistas aparece na citada memória lida numa das sessões da academia onde defendeu uma gênese sedimentar para as rochas da região: "fundado em observações mineralógicas, diversifico da opiniã o de Strange, Ferber, Fortis e Spallanzani, que a tribuem origem vulcânica às rochas que formam estes outeiros" ${ }^{\prime \prime 9}$.

A pós a visita à Itália, os filó so fos deveria m ir às minas de Eka terimburg 0 , na Rússia, o que não ocorreu, a ssim como nã o foram à Ingla terra, onde deveriam visitar as minas da Escócia e do País de G ales. Também não foram à Espanha, visitar sobretudo as minas de Almadén. Contudo, estiveram nos países nórdicos. $\mathrm{N}$ a Suécia, Bonifácio recebeu autorização para "penetrar as usinas de ferro e de prata, bem como ter ing resso nas minas desses meta is", além de ter visitado a região de Svenska Bergslagen, rica em minas e minérios na Suécia centra ${ }^{50}$. Cabe registrar que Bonifácio foi admitido como membro da Real Academia de Ciências de Estocolmo no dia 25 de outubro de $1797^{51}$.

Já na Dinamarca, na cidade de Kungsberg, Bonifácio visitou as usinas e minas de ferro e de prata. Sabemos que esteve também na N oruega, uma vez que recebeu autorização para a viagem após estadia na Suécia. Contudo não obtivemos informações sobre as suas atividades científicas no local.
46 HALLAM, 1982

47 FALCÃO, 1963, v. 3, p. 176.

48. Registremos que durante a sua viagem pela Itália, José Bonifácio não esteve em Roma, fato que pode ser explicado pela própria lógica da viagem, "adquirir conhecimentos mineralógicos e de outras partes da Filosofia Natural", ao contrário de outros letrados como Gibbon e Montesquieu, que visitaram as ruínas romanas para buscar 0 entendimento do curso da História. Cf. CAVALCANTE, 2001.

49. FALCÃO, 1963, v. 1, p. 145.

50. Ibid., v. 3, p. 172.

51. Ibid., p. 183. 

Exposé succinte des caractéres et des propriétés de plusieurs nouveaux minéraux de Suéde et de N orwége, avec quelques observations chimiques faites sur ces substances, publicada em francês no Journal de Physique, de $\mathrm{C}$ himie et de $\mathrm{H}$ isto ire $\mathrm{N}$ a turelle, em1 800 , e em inglês no A Journal of $\mathrm{N}$ atural Philosophy, Chemistry and the Arts, em 1801 .

A memória consiste na descrição das espécies minerais pesquisadas pelo autor durante as suas viagens pela Suécia e $N$ oruega, descrição essa enviada a Beyer, inspetor de minas em Schneeberg. Ao todo foram 12 espécies minerais, sendo que quatro eram minerais até então desconhecidos e as outras oito eram variedades de minerais. Para tais pesquisas, como o próprio Andrada a firmou, fo i de extrema importância a a juda do professor $A$ bilgaard (Peter $C$ hristian Abilgaard - 1740-1801), que Ihe auxiliou nas a nálises em Copenha gue. A descrição dos minera is foi feita seguindo a "sua própria maneira, a ssim como os resultados das análises que já havia feito de alguns deles, junto com os outros, que no momento são o objeto da minha ocupação, e daqueles que o Professor Abilgaard havia se comprometido em fazer as análises em Copenha guem"52.

Embora Bonifácio tenha anunciado que as descrições dos minerais eram basea das em seu próprio método, esse pouco diferia dos métodos utilizados pelas escolas cristalográficas da época e por W erner, que descreveu os minera is com base em suas propriedades e características externas.

Abraham $G$ ottlob W erner também foi o grande responsável pela classificação do reino mineral, uma vez que rejeitou a aplicação a esse reino do sistema de classificação proposto por Lineu para o reino vegetal baseado no sistema sexual das plantas. 0 mineralogista saxão afirmou que os minerais deveriam ser classificados de acordo com a sua composição, uma vez que nela residia a sua característica essencial. $0 \mathrm{~s}$ minera is seriam classificados levando em conta as suas características externas e sua composição química ${ }^{53}$.

No ano de 1774, W erner publicou uma obra intitulada Sobre as características externas dos minerais, em que apresentou uma técnica para identificar os minerais por meio dos sentidos humanos. Entre essas características estavam a forma do cristal, a superfície externa, o brilho externo, a fratura, a forma dos fragmentos, a transparência, os traços, a cor, a dureza, a flexibilidade, a adesão à língua e o som. Ele descreveu as características individua is dos minerais de maneira detalhada e as subdividiu de uma forma que os maximizava pela utilidade da identifica ção mineral. Apenas para a cor vermelha, W erner distinguiu 13 variedades diferentes.

W erner esta va convencido da importância das características externas não a penas para a identificação dos minerais, mas ta mbém para o estudo de sua composição. Ele justificava que uma vez que a aparência de um mineral muda quando sua composição química é alterada, deve haver uma correlação entre a composição e as características externas. Por outro lado, ele reconhecia que as características externas não podiam formar a base de um sistema natural. 
Ele escreveu:

0 ne can indeed recognize in the external carachter of minerals the diferences of their compostion, provided both are previously determined, but the correlation between these two features cannot be discovered in them ${ }^{54}$.

Dessa forma, ele estava convencido, em definitivo, que os sistemas minera is deveriam ser baseados na composição química e nas propriedades e características externas.

Por meio do diagnóstico de combinações específicas de qualidades, ba sea do em característica s externas, os tip os minera is poderiam ser reconhecidos com rapidez e por meios relativamente simples. W erner tornou-se muito famoso, sendo considerado como o supremo mestre de um método de identificação incomparável na mineralogia. Com seu trabalho, ele estabeleceu uma perfeita versão do método histórico natural de identificação mineral, e, simultaneamente, uma metodologia para a mineralogia como uma disciplina, que começou a emergir como uma ciência distinta da História N atura $\left.\right|^{55}$.

Além de W erner, o cristalografista francês Romé de L'Isle (1736-1790) ta mbém dispôs um conjunto de características externa s como determinantes das espécies minera is. Entre elas esta vam a forma cristalina, a dureza e o peso específico. Contudo, o trabalho desse homem de ciência francês difere-se daquele do saxão pelo fato de aplicar o sistema de classificação de linneu a o reino mineral.

Bonifácio ao descrever os minerais baseou-se em propriedades e características externas como a cor, o peso específico, a forma dos fragmentos, a textura, a transparência, o brilho, a presença de "formas cristais", a clivagem e o local de ocorrência, ou seja, as mesmas utilizadas por W erner e Romé de L'Isle em seus diferentes sistemas de classificação dos minerais.

O s quatro minerais descritos na memória, pela primeira vez, de acordo com as suas características e propriedades externas foram o espodumênio (L Al $\left[\mathrm{Si}_{2} \mathrm{O}_{6}\right]$ ), a petalita ( $\left.\mathrm{L}\left[\mathrm{AISI}_{4} \mathrm{O}_{10}\right]\right)$ ), a criolita ( $\mathrm{N} \mathrm{a} \mathrm{a}_{3} \mathrm{AIF}$ ) e a escapolita (um grupo de minerais semelhante a o grupo de feldspatos da classe dos plagioclásios, constituindo uma série de crista is mistos). Por sua vez, as variedades de minerais descritas foram: acanticônio (variedade de epídoto), salita (mineral da série dos piroxênios - silicato de cálcio, magnésio e ferro), cocalita (mineral de ferro da série de piroxênios), ictioftalmo (silicato de cálcio e potássio contendo flúor; nome a tual: a pofilita), indicolita (variedade de turmalina, silica to de boro), afrizita (variedade negra, férrea de turmalina; já havia sido descrita em 1524 por J. $M$ athesius e conhecida sob o nome de schörl), wernerita (denominada assim em homenagem a o mestre Abraham G ottlob W erner; essa denominação hoje está em desuso ou é usada como sinônimo para escapolita), alocroíta (variedade de granada entre andradita e silica to de ferro e cálcio) e grossulária (silicato de alumínio e cálcio; a denominação alocroíta está em desuso).

Bonifácio não se preocupou apenas com o conhecimento das características externas dos minerais descobertos, mas também em fornecer
54. Apud OSPOVAT, 1981. 
56. FALCÃO, 1963, v. 1, p. 213.

57. GUNTAU, 2000.

58. Esse documento está transcrito na obra de DOLHNIKOFF, 1998.

59. Ibid., p. 349. dados sobre os testes a nalíticos e químicos, realizados para o reconhecimento das a mostras. Citaremos qua tro exemplos.

1 - Acanticônio - Em frio, é insolúvel nos ácidos nítrico e sulfúrico.

2 ㅇ Espodumênio - 0 ácido nítrico não dissolve o espodumênio, nem produz qualquer efervescência.

3 o Petalita - A Petalita é infusível ao maçarico, e não perde sua cor nem seu brilho; com o bórax ela dá um vidro branco e transparente, e com 0 sal microscômico uma espécie de pérola de um branco amarelado; em grão ou pó ela não faz nenhuma efervescência com o ácido nítrico; ela se dissolve um pouco com o tempo.

4 o C riolita - No ácido nítrico ou muriático a criolita é insolúvel. Com grande concentração de ácido sulfúrico é fortemente efervescente, emitindo vapores gasosos que atacam 0 vidro ${ }^{56}$.

Com a descoberta dos quatro novos minera is e a sua descrição escapolita, criolita, espodumênio e petalita -, Bonifácio passou a pertencer, em 1800 , a um grupo de mineralogistas reconhecidos, como I. Born, A. G. Ekeberg, R. J. Haüy, A. G. W erner, por ter descoberto toda uma série de novas espécies, num período em que a mineralogia estava especialmente em ascensão. 0 reconhecimento do trabalho de José Bonifácio ocorreu no ano de 1868, quando o minera logista americano J. Dana designou em sua homenagem a granada de ferro e cálcio como andradita $\left(\mathrm{C} \mathrm{a}_{3} \mathrm{Fe}_{2}\left(\mathrm{SiO}_{4}\right)_{3}\right)^{57}$.

0 utro documento bastante interessante relativo à viagem científica é - Diário de observações, e notas sobre as minhas leituras, conversações e passeios, que José Bonifácio escreveu quando estava na Dinamarca ${ }^{58}$.

No primeiro dia (22 de outubro), apresentou o método estabelecido para os estudos, que compreendia pela manhã, o ler e ver, e, à tarde, o conversar e perguntar. Ele somava aos estudos a conversação com os sábios, com os homens de ciência, o que the permitiria "iluminar" o espírito e alcançar o conhecimento. Adema is, afirmou que os livros mais interessantes leria duas vezes e faria extratos à maneira de "G ibon (Edward Gibbon - historiador inglês) e Forster, 0 filho (G eorg Foster)".

Após se referir a sua chegada à Dinamarca e a sua recepção por João Rademacker, militar e diplomata português que desempenhava a função de representante de Portugal naquele país, Bonifácio comentou sobre as leituras que realizou, sobretudo as do campo da mineralogia. N esse primeiro dia, ele afirmou ter relido as obras de Ezmark, principalmente suas idéias sobre o rictognosia e as notícias de Petersen sobre as práticas montanhísticas na Suécia. E entre as outras obras mineralógicas que faziam parte das suas leituras diárias estavam:

L vários cadernos do M agazin Encyclopédique, o terceiro volume da M ineralogia de Esthner, 0 tratado Uber M ineralogie, und das M ineralogische Studium; não acabei Schelling, Ideen zu einer Philosophie der $\mathrm{N}$ atur, a mineralogia de Lineu $[. . .]^{59}$. 
Aos livros de estudos mineralógicos, adicionava as memórias de Literatura Portuguesa e os trabalhos de Edward G ibbon.

Porém, para melhorar os seus escritos, uma vez que reclamava que eles eram "secos" por causa do "estudo dos nomencladores e sistemáticos que tem apagado a minha imaginação", Bonifácio se propunha a exercitar-se na arte de "débrouiller mes idées com clareza, dignidade e graça"60. Pa ra conseguir alcançar o talento da narração e dos detalhes importantes, deveria ler e imitar Tito Lívio, Cícero, A ristóteles, Tácito, a utores da antigüidade clássica, assim como Voltaire, G ibbon, Buffon, Herder, autores da llustração.

Essa prática de José Bonifácio, como aparece no seu Diário de observações..., de registrar o que já havia lido e o que deveria ler, aparece ta mbém em manuscritos a vulsos que estão presentes nas suas coleções situadas nos a rquivos do IHG B e do M useu Paulista. A especificidade dessas fontes documentais reside no fato delas permitirem conhecer 0 universo das leituras feitas pelo naturalista. Por exemplo, no a rquivo do Instituto Histórico, há um manuscrito no qual Bonifácio forneceu uma relação de livros ingleses, franceses e portugueses, dos mais variados assuntos, que acreditamos que alguns ele já teria lido (ou não), pois a lado da obra aparece um comentário sobre ela, mostrando assim que estava a par da cultura científica do seu tempo:

Le Botaniste cultivateur par M r. du M ont de Couviet Paris, 1805. (excelente)

0 Recens. (te) das viagens de Vancouver (M ontr. April. 1799)

Conta ver: $\mathrm{N}$ ewton writtes gruxo gevete des benevergung $2 \cong$ Von Rohde, 1789.

Para a nova lição de Mar do Dus por Bockman. May, 1799, n. 172.

0 Deporico, osia minerario, par Le Colline Pisane. [sic]

Voyages complete de toutes les parties de L'Attas mineralogique de la France par Mannet. 1 vol. 4. 1799.

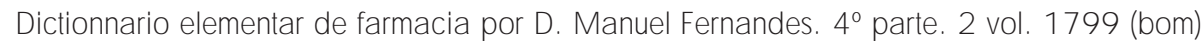
Annales de chime. $N .086$. Vem novas do Egito sobre ciências por Fourcroy.

Manuel d' un cours de chymie par Bouillon La G range. 2 Vol. G r. 8 (12 fr.) 1799.

Auper cryp to gamicae, por Joh. He Dwig. Lip. 1785.

G eorge Rudolphi Boehmer 2‥ Commentatio Physico-Botanica de plantarum emine. [sic] Histoire de Kentucke. $2 \cong$ de John Fulson, tra duit. Por M r. Parraud. Par [sic] 1786. 1 vol.

Essai sur la lithologie des envisors de [sic] Etienne [sic]

Memoires d'Agriculture, publié par laa Societé Royale d'Agriculture de Paris.

Dispertationes Batanice de Malva, [sic], Paris.

Institutio rum politicarum elementa; Botanica A. P. Francechinis Barnabita.

Theorie des machines afeu par M r. de M ialland. Vien (1784).

Essai sur l'histoire naturelle des roches, precedé d'un exposé systemátique des terres, et des presses, par Mr. de Launay. Bruss. (1766)

Essai meteorológique de M r. Coaldo (1786).[...]

Description et usage d'un cabinet de physique experimentale par Sigaud de la Fond. 2 a ed. por Rouchard. Par 2 vol. 1784. [...]

Memoires of the present state of science and scientifique institution in France by $A$. B. Granville ${ }^{61}$.

Em outra relação de livros, presente na coleção do M useu Paulista, ele listo u uma série de livros científicos, sobressa indo os do campo da mineralogia,
60. Ibid., p. 349-350.

61. ANDRADA E SILVA, Relação de livros ingleses... 


\section{Ibid.}

63. DOLHNIKOFF, 1998, p. 355.

64. NOVAIS, 1984 deixando transparecer a atualização do seu pensamento científico nesse campo da História N atural:

Lehrbuch der M ineralogie von Haug n. V. Kaosten tom. 1.8 vo. 1804. (Com notas e observações).

Archiv der Agriculturchemir V. Hermbstadt. 1r. Th. 1804.

Viaggio G eologico per diverse parti meridionale dell'Italia in Lettere di Erm. Pini. 8 vo. 1804. Lettere...sulle Indie 0 rientai. Philadelph. 8 vo. Por Pai. 1804.

$M$ ineralogische Reisen durch Schottland von Jamison, \&a. 40 ( 3 th. 12 p.)

The M ineralogy of Derbyshire \&a. par John M awe. 8 vo. Londr.

Black, Lectures on the elements of chemistry, 2 vol. 4 ㄴ Londr. $1804^{62}$.

Retornando à análise do Diário, no segundo dia (23 de outubro), José Bonifácio iniciou relatando - em francês - que deveria ler determinados autores e as suas respectivas obras. Entre esses estudiosos estava Leclerc e a sua Ars critica, a lém de outras obras filosóficas e científicas; as obras de Pierre $\mathrm{G}$ assendi, "filósofo dos literatos e litera to dos filósofos"; o Leibiniz literário; e o Dicionário histórico e crítico de Pierre Bayle. Em outra passagem argumentava que cumpria "reler o Journal des Savants, da Bibliótheque universelle et raisonée de Le clerc, et la Republique des lettres de Bayle. Ler sobre as idéias físicas dos antigos mr. Frenet, $M$ endel, $A b c$ des belles lettres" ${ }^{\prime \prime 3}$. Também afirmava a necessidade que sentia de estudar o grego e de recomeçar uma leitura aprofundada dos clássicos latinos, deixando assim transparecer o valor que conferia à tradição clássica.

0 cruzamento das leituras de autores e das suas respectivas obras, tanto os da llustração quanto os da tradição clássica, é uma característica que percorre as páginas do diário do Andrada. Ele não separava os autores por suas épocas, lendo-os conjuntamente e fazendo a ssim as suas respectivas sínteses. Portanto, associava as leituras dos "modernos", como Bacon, Leibiniz, Fontenelle, Bayle, M ontesquieu, entre outros, com os "antigos", como Aristóteles, Sêneca, Tácito, Virgílio, Plutarco, etc.

A análise das Instruções organizadas pelo ministro Luiz Pinto de Souza nos permite afirmar que os três enviados da Coroa portuguesa visita ram quase todos os loca is sugeridos por ele, com exceção das minas da Rússia, Ingla terra e Espanha. $N$ ão sabemos as razões pelas qua is não estiveram presentes nesses países. Essa viagem de aperfeiçoamento técnico no campo da mineralogia e da mineração por diversos países da Europa C entral e do N orte fazia parte da política portuguesa que visava a cooptar os estudiosos portugueses, nascidos na metrópole ou em qualquer parte de seu Império colonial, com o intuito de ajudar a promover a modernização do Estado. Eles eram enviados para os principa is centros científicos europeus, com o intuito de observar o estado das ciências nesses países e se aperfeiçoar, para assim poder levar para Portugal os ares da modernidade ${ }^{64}$. Essa prática de adesão às ciências modernas era buscada em diferentes lugares, selecionando os conhecimentos que mais thes interessava, uma vez que os centros científicos nem sempre eram os mesmos. No caso da viagem aqui analisada, privilegiou-se França, Freiberg, Itália e países nórdicos. 
A dimensão política vinha a coplada à científica. A viagem fazia parte do processo de modernização do Estado português no período do governo de D. Maria I, quando buscou-se incentivar a formação de funcionários especializados com o intuito de ocupar cargos públicos estratégicos, sobretudo no campo da administração. Após a realização dessa viagem, José Bonifácio e M anuel Ferreira da Câmara viriam a ocupar importantes funções no campo da mineração em Portugal e na colônia, destacando-se a administração conjunta das minas, matas e bosques.

A profissionalização das atividades científicas de José Bonifácio na Intendência G eral das M inas e M etais do Reino:

um espaço de pesquisa das produções natura is minerais

Para José Bonifácio, a viagem foi imprescindível para a especialização de sua trajetória naturalista, tornando-se, como ele próprio afirmava, um "metalurgista de profissão"65. Ao retornar a Portugal, D. Rodrigo de Sousa Coutinho, ministro da M arinha e Ultramar, considerou-o o naturalista indicado para a realização de seus projetos. Assim Bonifácio foi chamado para criar a cadeira de M etalurgia da Universidade de Coimbra, participando a tivamente da llustra ção portuguesa ${ }^{66}$. Junta mente com esse carg 0 , a ssumiu outros na vida pública portuguesa, como o de intendente geral das M inas e M etais do Reino, membro do Tribunal das M inas, administrador das antigas minas de carvão de Buarcos, etc.

A partir desse momento, os seus estudos científicos passaram a ter de dividir o tempo com os cargos estatais, sobretudo a queles relativos à esfera administrativa portuguesa. Em outras palavras, o perfil de naturalista e 0 de homem público passaram a caminhar lado a lado na história de vida do personagem, não podendo ser dissociados. N ão são duas carreiras diferentes o u sucessivas, mas durante toda a sua vida em Portugal, ele levou simulta neamente uma vida de funcionário do Reino e uma vida de naturalista. José Bonifácio é um típico representante dos laços estreitos que se criam durante o reformismo llustrado português mariano e joanino entre os sábios e o governo, como já assinalamos.

A cooptação dos naturalistas pelo Estado, sobretudo no fim do século $X V I I I$, indica a valorização daqueles que detinham o conhecimento científico e técnico, principalmente para dar o seu parecer sobre os mais variados assuntos econômicos e administrativos. Em síntese, demonstra-se o reconhecimento do poder da ciência pelo Estado67.

N o período da Viradeira, ocorreu uma forte identificação entre ciência e política, ou melhor, entre aqueles que produziam o conhecimento científico e os que eram capazes de conseguir a poio e recursos financeiros necessários ao desenvolvimento das ciências. 0 Estado português a rregimentou os na turalistas da Academia Real das Ciências de Lisboa com o intuito de acumular várias
65. Sobre a atuação de José Bonifácio nalntendência das Minas ver VARELA, 2001, cap. 3.

66. VARELA; LOPES; FON SECA, 2003, p. 148-160.

67. MATOS, 1998. 
68. MUNTEAL FILHO, 1998.

tarefas, entre as quais podemos destacar o mapeamento, diagnóstico, conhecimento e orientação de políticas direcionadas ao levantamento das riquezas naturais, ou melhor, das "produções natura is" do território português e de to do o seu Império ultra ma rino. Esse fa to permite observa ro qua nto a a cademia por meio das suas propostas de cará ter científico esta va extrema mente conectada ao Estado português ${ }^{68}$.

Como exemplo está o caso de a rregimentação do na turalista José Bonifácio de Andrada e Silva por D. Rodrigo para ocupar uma série de cargos públicos estata is no campo da esfera administrativa. D. Rodrigo não pouparia esforços em gastar os recursos necessários para a pesquisa das produções naturais do Reino de Portugal, sobretudo os minerais, e para a preservação das matas e dos bosques.

José Bonifácio foi nomeado intendente das M inas do Reino de Portugal pela Carta Régia de 18 de maio de 1801 . Pela mesma foi encarregado de dirigir e administrar as "M inas, e Fundições de Ferro de Figueiró dos Vinhos". Para tal, seria condecorado com uma "beca honorária com o predicamento de primeiro banco", e ficaria mantida a pensão de 800 mil-réis de que havia gozado durante o tempo das suas viagens pela Europa. Ainda na mesma Carta, ficava encarregado de estabelecer e firmar o ensino da Cadeira de M etalurgia na Universidade de Coimbra durante o período de seis anos. Após o qual, ficaria unicamente ocupado da Intendência das M inas e M etais, assim como das de Figueiró dos Vinhos, e da abertura das minas de carvão de pedra.

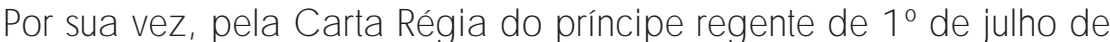
1802 , o naturalista José Bonifácio foi arregimentado para assumir a direção da administração das sementeiras e plantações nos a reais das costas portuguesas, que começou pelo Couto de Lavos. Essa Carta Régia vinha associar a administração das matas e bosques à das minas na pessoa do naturalista José Bonifácio, homem que havia viajado por diversos países europeus e to ma do conta to com os modernos conhecimentos científicos relacionados a esses ramos da administração pública. 0 fato mostra a importância que o Estado burocrático português dava aos filósofos naturais, e, no caso em questão, a necessidade de minas e bosques serem regulados por princípios científicos com o objetivo de promover a utilidade pública.

Um novo regimento para 0 funcionamento das minas e estabelecimentos metálicos do Reino foi baixado a mando do príncipe regente em função da criação da Intendência e da nomeação de José Bonifácio. 0 alvará de 30 de janeiro de 1802 definiu a competência do intendente geral das $M$ inas e $M$ etais do Reino e a sua respectiva área de atuação.

0 intendente geral seria o diretor e administrador das M ina s e Ferra rias de Portugal, estando a ele subordinadas todas as pessoas e oficiais que nela prestassem assistência e trabalhassem, assim como todos os indivíduos empregados nas minas e estabelecimentos minerais portugueses, fossem funcionários do rei ou de companhias particulares de minerações e apurações. Além de administrar as minas, também ficava encarregado da direção e administração dos bosques e das matas. 
Contudo, no ano de 1804 , por decreto de 4 de maio, a administração das minas e estabelecimentos mineiros do Reino foi entregue à direção da Fábrica das Sedas e 0 bras das Águas Livres. Esse decreto anulava as a mplas a tribuições e poderes concedidos ao intendente para inspecionar tudo que dissesse respeito às minas, ferrarias, bosques e matas, concedidos pelo alvará supracitado de 1802. Diniz ${ }^{69}$ justificou tal a to em função da demissão de D. Rodrigo de Sousa C outinho, amigo pessoal de José Bonifácio, organizador da Intendência G eral das M inas e M etais do Reino e inspetor geral das mesmas, do cargo de ministro da Fazenda e de presidente do Real Erário. 0 seu sucessor, Luiz de Vasconcelos e Sousa, o substituiu na presidência do Real Erário e entregou a administração mineira à direção da Fábrica das Sedas.

José Bonifácio a presentou à Academia de Ciências algumas memórias mineralógicas ${ }^{70}$. N esses textos, demonstrou as suas atividades práticas de mineração nas regiões onde pesquisava, assim como detalhou minuciosamente cada local onde eram encontrados os minerais, a descrição dos mesmos e a sua importância para o desenvolvimento da nação portuguesa.

Essas memórias relacionam-se ao cargo estatal que o Andrada exercia de intendente geral das M inas e M etais do Reino. A té então, as "artes mineiras", ou seja, desenvolvimento, lavra, tratamento e fiscalização das explorações das minas, estiveram sob a alçada do Corpo de 0 ficia is de Artilharia ${ }^{71}$. Pela primeira vez, ocupava o cargo um filósofo natural dedicado à pesquisa e investigação da natureza mineral.

$\mathrm{N}$ as memórias ganha destaque a tentativa do autor de inventariar 0 "estado da arte" da mineração em Portugal. N elas, ele mapeou os problemas existentes na atividade mineradora e apresentou propostas para superar os entraves existentes ao seu desenvolvimento. O filósofo tentou fazer um levantamento extenso e pormenorizado das riquezas minerais presentes no solo português e destacou as potencialida des das mesmas para a nação. A mineração, ao lado da agricultura, constituiria a base funda mental das riquezas permanentes do Estado luso.

Por meio das suas memórias científicas, ganhando destaque as mineralógicas, José Bonifácio ajudou a criar e a sustentar um conjunto de redes de informaçã $0^{72}$ que permitiu ao Estado do período da Viradeira conhecer de forma ma is a profundada e precisa todo o território português, ou seja, reconhecer os limites físicos dessa soberania e as potencialidades econômicas do território administrado. Todas as informações fornecidas pelo na tura lista e recebidas pelos dirigentes do Estado deveriam contribuir para o conhecimento global do espaço luso.

0 conjunto de informações presentes nas memórias do na tura lista José Bonifácio não se destinava a fins somente administrativos nem a limentariam uma ciência especulativa ou teórica. 0 saber científico tinha um caráter eminentemente prático, pois a ciência que ele praticava tinha como objetivo ser útil. As descrições e amostras de produtos, sobretudo os minerais, que foram recolhidos durante as suas viagens de campo por diversos pontos do território português destinavamse não só à inventariação, catalogação e classificação das espécies ou ao
69. DINIZ, 1939, p. 31.

70. Sobre as memórias mineralógicas de José Bonifácio produzidas no âmbito da Intendência Geral das Minas e Metais do Reino, inclusive algumas que permaneceram manuscritas até os dias de hoje, ver VARELA; LO PES; FONSECA, 2002, p. 405-426.

71. FERREIRA, 1988.

72. DOMINGUES, 2000. 
reconhecimento das potencialidades naturais, mas também à contribuição para o desenvolvimento econômico do Reino e o incremento das indústrias, manufa turas e do comércio, entre outros fatores.

O conjunto de informações científicas contidas nas memórias de Bonifácio estava baseado na observação e na experimentação. 0 conhecimento científico, para ele, tinha que ser prático. A ciência que o entusiasmava era aquela de matriz baconiana que tinha como função resolver problemas concretos. A essa característica juntava-se 0 fato de sempre fazer a nálises prospectivas em seus estudos e propor a necessidade de utilizar os recursos natura is de forma planejada e racional, pois eles continham grandes potencialidades econômicas para o Estado português. Dessa forma, pode-se afirmar que o conhecimento científico estava integrado a um programa que, desenvolvido na Intendência das $M$ inas e $M$ eta is do Reino e publicado em memórias na Academia Real das Ciências, tinha repercussões na ciência, na economia e na política.

As memórias elaboradas pelo autor se referiam a trabalhos práticos, descritos nos menores detalhes. Elas explicitavam como essa política portuguesa de a proveita mento racional dos recursos natura is, sobretudo os minera is, foi efetiva da e posta em prática pela Intendência das M inas, órgão estatal dirigido por José Bonifácio, locus de produção científica e auxiliar na criação e sustentação do já mencionado conjunto de redes de informação. As memórias mineralógicas constituíram verdadeiros estudos a na líticos das potencialidades minerais do país, por meio de exames cuidadosos de detalhes, trabalhos de campo, mapeamentos acoplados às informações históricas obtidas tanto de documentos de arquivos como de ruínas arqueológicas - que muitas vezes datavam da ocupação romana do território português ou dos antigos reinados - outras do conhecimento empírico a cumulado pelos lavradores, "rústicos" do local, ou seja, a política da Intendência parecia priorizar as regiões com potencial mineralógico a ser checadas, confirmadas, e mais uma vez exploradas racional e cientificamente.

A quantidade de minerais identificados por José Bonifácio em seu trabalho na Intendência vinha ao encontro de uma política estatal que tinha como objetivo a produção mineral. Em função disso, ele examinou as ocorrências de diversos minerais, como o ouro, o chumbo, o ferro, a prata, entre outros.

Q uanto à prática científica de José Bonifácio, observamos que no campo da mineralogia, ele seguiu o common sense dessa ciência no período do fim do século XVIII e início do XIX inserindo-se em suas correntes principais tanto pelos termos que empregava como pela sua metodologia de trabalho. Ele preocupava-se em descrever, identificar e classificar os materia is minera is em seu local de ocorrência, dando à sua atividade um caráter geográfico, onde o trabalho de campo adquiria papel essencial.

Uma outra característica da sua prática científica foi a ênfase na observa ção das regularidades permanentes. A prática científica de José Bonifácio analisada por meio das suas memórias insere-se em uma tra dição de pesquisa que buscava relatar o que Kenneth Taylor chamou de "regularidades permanentes" ${ }^{13}$. 0 estudo de tais regularidades, também denominadas de "condições gerais ou constantes" ou "regularidades de disposição", era uma 
prática dominante nos estudos geológicos do século XVIII, estando presente nos trabalhos de Buffon, Louis Bourguet, $\mathrm{N}$ icolas Desmarest, Horace Benedict de Saussure, Jean-André Deluc, entre outros. 0 interesse em identificar e estudar as regularidades refletia o empirismo habitual da época, assim como o desejo de fazer generalizações, de se criar leis no domínio da geologia. 0 s autores citados estavam preocupados em estudar os grandes traços dos continentes e dos mares, a altura, a localização, a orientação e a espessura das montanhas, o movimento das águas dos mares e dos rios, a disposição das camadas estratigráficas e os seus minerais, entre outras regularidades. C abe ressaltar ainda que nos trabalhos da queles a uto res impera va o estudo das regula rida des estáticas entendida s co mo conseqüência de processo e não como as causas, a explicação de como um determinado fenômeno ocorreu.

José Bonifácio enfatizou em suas memórias as regularidades estáticas, buscando sempre apontar o local das minas, fazer a descrição do terreno, quais os materiais que o formavam, a quantidade de minerais, como estavam contidos nas camadas estratigráficas, a sua cor, forma, tamanho, peso e dureza, se esta vam em profundidade ou superfície. Essas são as principais regularidades observadas pelo filósofo em suas dissertações.

Embora não tenha se dedicado enfaticamente a reflexões teóricas sobre a forma ção da crosta terrestre em suas memórias, o que ma is Ihe interessa va era saber a potencialidade econômica dos minerais, para assim ajudar a resolver os graves problemas econômicos que Portugal enfrentava naquele momento.

José Bonifácio foi um naturalista que se caracterizava por ser eclético e pragmático. 0 ecletismo e o pragmatismo eram traços do pensamento llustrado do século XVIII, uma vez que o próprio Voltaire afirmava "meu a migo, sempre fui eclético". E, assim também agia Bonifácio, que bebia em todas as fontes e tirava delas sempre o melhor, deixando de lado aquilo que não considerava de utilidade imediata. Um exemplo cla ro desse ecletismo era a utilização pelo autor de diferentes sistemas de classificação dos minerais, como os de Carl von Lineu, Abraham G otto b W erner, Johann $G$ otschalk W a hlerius, entre outros, que lhe permitiu classificar inclusive quatro novos minerais como já comentamos. A recorrência a diversos sistemas era necessária para que ele pudesse conhecer e identificar os produtos minera is úteis a os interesses da Coroa portuguesa.

A a tuação de José Bonifácio contribuiu para um duplo processo. Em primeiro lugar, a Intendência foi espaço institucional que possibilitou a profissionalização das suas atividades cient́ficas. Em segundo, a instituição fo $i$ um espaço de difusão das "luzes" das ciências pela socieda de lusa, contribuindo para o processo de institucionalização das ciências natura is em Portugal. Suas memórias científicas, fruto de seus trabalhos práticos de campo, foram o exemplo maior dessa contribuição. Por outro lado, tentou modernizar a administra ção das minas, das matas e dos bosques, buscando tornara Intendência uma empresa competitiva e capaz de funcionar como a quelas presentes em regiões da Saxônia, Freiberg, França, Itália, etc. Tudo isso foi feito tendo sempre em mente ser 0 "mais humilde e fiel súdito português". 


\section{REFERÊN CIAS}

ANDRADA E SILVA, J. B. Notas filosóficas, algumas em franoês. s./l.: IHGB, s./d., livro 192, pasta 59.

.Notas sobre o alambique. s./l.: IHGB, s./d., livro 192, doc. 36.

.Relação de livros ingleses, franceses e portugueses. s./l.: IHGB, s./d., livro 191, doc. 60.

.Diário de despesas e lições na cidade de Paris. s./l.:IHGB, s./d., livro 191, pasta 35.

1503.

.Relação de livros.Assunto: mineralogia e geologia. s./l.: Museu Paulista, s./d., s./l., doc.

AN DRADA E SILVA, J. B.; SILVEIRA, F. E. R. da. Parecer sobre o método de desinfetar as cartas vindas de países estrangeiros. Portugal:Arquivo Nacional da Torre do Tombo. Ministério do Reino/Negócios da Saúde Pública, maço 970, caixa 1085, 1814.

ARLET, G. D’Héphiasitos à Sphia Antipolis - mineurs et forgérons. St. Etienne: Gédim, v. 1, 1991.

BARNES, B. Sobre ciencia. Barcelona: Ed. Labor, 1987.

BENSAUDE-VINCENT, B; STENGERS, I. História da química. Portugal: Instituto Piaget, 1996.

BRIGO LA, J. C. P. Coleções, gabinetes e museus em Portugal no século XVIII. Lisboa: Fundação Calouste Gulbenkian/Ministério da Ciência e Ensino Superior, 2003.

CAVALCANTE, B. José Bonifácio: razão e sensibilidade, uma história em três tempos. Rio de Janeiro: FGV, 2001.

CURTO, D. R. D. Rodrigo de Sousa Coutinho e a Casa Literária do Arco do Cego. In: A casa literária do Arco do Cego (1799-1801). Bicentenário: sem livros não há instrução. Lisboa: Biblioteca Nacional/Imprensa Nacional/Casa da Moeda, 1999.

CZRESNIA, D. Do contágio à transmissão: ciência e cultura na gênese do conhecimento epistemológico. Rio de Janeiro: Ed. Fiocruz, 1997.

DINIZ, J. P. Subsídios para a história da montanhística. Lisboa: Editorial Império, 1939.

DOLHNIKOFF, M. (Org.). Projetos para o Brasil/José Bonifácio deAndrada e Silva. São Paulo: Companhia das Letras, 1998.

DOMINGUES, Â. Para um melhor conhecimento dos domínios coloniais: a constituição de redes de informação no Império Português em finais de setecentos. Ler História. Lisboa, n. 39, 2000.

DUARTE, A.G.;DIAS, J.P. de S. A segurança da inocência do papel:a desinfecção da correspondência em Portugal (1637-1897). In: Actas do 1o Congresso Luso-Brasileiro de História da Ciência e da Técnica.Évora: Universidade de Évora, 2001.

ELIAS, N. A sociedade de Corte. Lisboa: Editorial Estampa, 1995. 
ELLEMBERGER, F. Histoire de la géologie. Paris:Technique et documentation; Lavoisier, 1994.

FALCÃO, E. C. de. (Org.). Obras científicas, políticas e sociais de José Bonifácio de Andrada e Silva. 3v. Santos: Rev. dos Tribunais, 1963.

FALCON , F. J. C. Da llustração à revolução - percurso ao longo do espaço-tempo setecentista. Acervo. Revista do Arquivo Nacional. Rio de Janeiro, v. 4, n. 1, jan.jun., 1989.

FERREIRA, M. Portugal. José Bonifácio de Andrada e Silva (mineralogista, acadêmico, mineiro do início do século XIX). Memórias e notícias. Publ. mus. lab. mineral. geol. Coimbra, Univ. de Coimbra, n. 106, 1988.

FERRONE,V. O homem de ciência. In:VOLVELLE, M. (Org.) O homem do Iluminismo. Lisboa: Ed. Presença, 1997.

GUNTAU, M.The natural history of the earth. In:JARDINE, N.; SECORD, J. A.; SPRAY, E. C. (Eds.). Cultures of natural history. Cambridge: Cambridge University Press, 1997.

. José Bonifácio de Andrada e Silva - estudos e trabalhos científicos na Europa Central. In: FIGUEIRÔA, S. F. de M. (Org.). Um olhar sobre o passado: história das ciências na América Latina. Campinas: Unicamp, 2000.

HALLAM ,A. Grandes controversias geológicas. Barcelona: Labor, 1982.

HOOY KAAS, R. The historical and philosophical background of Hauy's theory of crystal structure. AWLSK, Klasse der Wetenschap pen 56, n. 2, 1994.

KURY, L. B. O Império dos miasmas: a Academia Imperial de Medicina (1830-1850). 1990. Dissertação (Mestrado em História) - Instituto de Ciências Humanas e Filosofia, Universidade Federal Fluminense, Rio de Janeiro,1990.

KURY,L.B.; MUNTEAL FILHO, O.Cultura científica e sociabilidade intelectual no Brasil setecentista: um estudo acerca da sociedade literária do Rio de Janeiro. Acervo. Revista do Arquivo Nacional. Rio de Janeiro, v. 8, 1995.

LAUDAN, R. From Mineralogy to Geology: the Foudations of a Science, 1650-1830. Chicago: The Univ. of Chicago Press, 1987.

MANUEL, F.; MANUEL, F. Utopian thought in theWestern World. Cambridge: Cambridge University Press, 1979.

MATOS, A. M.C. de. A ciência ao serviço da reforma do Estado: a química em Portugal no final do século XVIII-início do século XIX.In: JANEIRA,A. L. et al. (Eds.) Divórcio entre cabeças e mãos? Laboratórios de química em Portugal (1772-1955). Lisboa: Livraria Escolar Editora, 1998.

MUNTEAL FILHO, O. Domenico Vandelli no anfiteatro da natureza: a cultura científica do reformismo ilustrado português na crise do antigo sistema colonial (1779-1808). 1993. Dissertação (Mestrado em História Social da Cultura). Pontifícia Universidade Católica, Rio de Janeiro, 1993. 
.Uma sinfonia para o novo mundo: a Academia Real das Ciências de Lisboa e os caminhos da Ilustração luso-brasileira na crise do Antigo Sistema Colonial. 1998. Tese (Doutorado em História Social) - Instituto de Filosofia e Ciências Sociais, Universidade Federal do Rio de Janeiro, 1998.

NOVAIS, F. A. O reformismo ilustrado luso-brasileiro: al guns aspectos. Revista de História. São Paulo, n. 7, 1984.

NOVAIS, F. A. Portugal e Brasil na crise do antigo sistema colonial. 6 ed. São Paulo: Hucitec, 1995.

OSPOVAT, A. Abraham Gottlob Werner. In: GILLISPIE, C. C. (Org.). Dictionary of scientific biography. New York: Scribner's Sons, 1981.

RUDWICK, M. Minerals, strata and fossils. In: JARDINE, N.; SECO RD, J. A.; SPRAY, E. C. (Eds.). Cultures of natural history. Cambridge: Cambridge University Press, 1997.

SILVA, M. B. N. da. A cultura luso-brasileira: da reforma da Universidade à Independência do Brasil. Lisboa: Editorial Estampa, 1999.

SILVA, A. R. C. da. Construção da nação e escravidão no pensamento de José Bonifácio de Andrada e Silva (1783-1823). Campinas: Unicamp, São Paulo:Centro de Memória, 1999.

SILVA, C. P. da. O desvendar do grande livro da natureza:um estudo da obra do mineralogista JoséVieira Couto, 1798-1805. São Paulo:Annablume/Fapesp/Unicamp, 2002.

SO USA, O.T. de. História dos fundadores do Império do Brasil:José Bonifácio de Andrada e Silva. Rio de Janeiro: Livraria José Olympio, v. 1, 1957.

TAY LOR, K. L. Les lois naturelles dans la géologie du XVIII éme siécle: recherches préliminaires. Travaus du comite Français d’histoire de la geologia. Paris, troisième serie, t. II, 1988.

VARELA, A. G. "Juro-lhe pela honra de bom vassalo e bom português": filósofo natural e homem público - uma análise das memórias científicas do ilustrado José Bonifácio de Andrada e Silva em sua "fase portuguesa"(1780-1819). 2001. Dissertação (Mestrado em Geogências) Instituto de Geociência,Universidade Estadual de Campinas, Campinas, 2001.

VARELA,A. G.; LOPES, M. M.; FO NSECA, M. R. F. da. O Ilustrado José Bonifácio de Andrada e Silva e os estudos mineralógicos na Universidade de Coimbra. Revista da Sociedade Brasileira de História da Ciência. Rio de Janeiro, v. 1, n. 2, jul.-dez. 2003.

.Os minerais são uma fonte de conhecimento e de riquezas: as memórias mineralógicas produzidas por José Bonifácio de Andrada e Silva. História, ciências, saúde - Manguinhos. Rio de Janeiro, v. 9, n. 2, mai.-ago. 2002.

Artigo apresentado em 06/2004. Aprovado em 09/2004. 